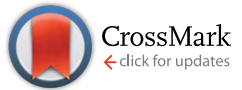

Cite this: Chem. Sci., 2016, 7, 3304

\title{
Synthesis, structure, spectroscopy and reactivity of new heterotrinuclear water oxidation catalysts $\uparrow$
}

\author{
Lorenzo Mognon, ${ }^{a}$ Sukanta Mandal, ${ }^{\text {b }}$ Carmen E. Castillo, ${ }^{\text {cd }}$ Jérôme Fortage, ${ }^{\text {cd }}$ \\ Florian Molton, ${ }^{\text {cd }}$ Guillem Aromi, ${ }^{\mathrm{e}}$ Jordi Benet-Buchhlolz, ${ }^{\mathrm{a}}$ Marie-Noëlle Collomb ${ }^{\mathrm{cd}}$ \\ and Antoni Llobet ${ }^{\star a f}$
}

Four heterotrinuclear complexes containing the ligands 3,5-bis(2-pyridyl)pyrazolate $\left(\mathrm{bpp}^{-}\right)$and $2,2^{\prime}: 6^{\prime}, 2^{\prime \prime}$ terpyridine (trpy) of the general formula $\left\{\left[\mathrm{Ru}^{\prime \prime}(\operatorname{trpy})\right]_{2}\left(\mu-\left[\mathrm{M}(\mathrm{X})_{2}(\mathrm{bpp})_{2}\right]\right)\right\}\left(\mathrm{PF}_{6}\right)_{2}$, where $\mathrm{M}=\mathrm{Co}^{\prime \prime}, \mathrm{Mn}^{\prime \prime}$ and $\mathrm{X}=$ $\mathrm{Cl}^{-}, \mathrm{AcO}^{-}\left(\mathrm{M}=\mathrm{CO}^{\prime \prime}, \mathrm{X}=\mathrm{Cl}^{-}: \mathrm{Ru}_{2} \mathrm{Co}-\mathrm{Cl}_{2} ; \mathrm{M}=\mathrm{Mn}^{\prime \prime}, \mathrm{X}=\mathrm{Cl}^{-}: \mathrm{Ru}_{2} \mathrm{Mn}-\mathrm{Cl}_{2} ; \mathrm{M}=\mathrm{Co}^{\prime \prime}, \mathrm{X}=\mathrm{AcO}^{-}: \mathrm{Ru}_{2} \mathrm{Co}-\right.$ $\mathrm{OAc}_{2} ; M=M n^{\prime \prime}, X=A c \mathrm{O}^{-}: \mathrm{Ru}_{2} \mathrm{Mn}-\mathrm{OAc}_{2}$ ), have been prepared for the first time. The complexes have been characterized using different spectroscopic techniques such as UV-vis, IR, and mass spectrometry. $X$-Ray diffraction analyses have been used to characterize the $\mathrm{Ru}_{2} \mathrm{Mn}-\mathrm{Cl}_{2}$ and $\mathrm{Ru}_{2} \mathrm{Mn}-\mathrm{OAc} \mathrm{C}_{2}$ complexes. The cyclic voltammograms $(\mathrm{CV})$ for all four complexes in organic solvent $\left(\mathrm{CH}_{3} \mathrm{CN}\right.$ or $\left.\mathrm{CH}_{2} \mathrm{Cl}_{2}\right)$ display three successive reversible oxidative waves corresponding to one-electron oxidations of each of the three metal centers. The oxidized forms of the complexes $\mathrm{Ru}_{2} \mathrm{Co}-\mathrm{OAc} \mathrm{c}_{2}$ and $\mathrm{Ru}_{2} \mathrm{Mn}-\mathrm{OAc_{2 }}$ are further characterized by EPR and UV-vis spectroscopy. The magnetic susceptibility measurements of all complexes in the temperature range of $2-300 \mathrm{~K}$ reveal paramagnetic properties due to the presence of high spin $\mathrm{Co}(॥)$ and $\mathrm{Mn}(॥)$ centers. The complexes $\mathrm{Ru}_{2} \mathrm{Co}-\mathrm{OAc}_{2}$ and $\mathrm{Ru}_{2} \mathrm{Mn}-\mathrm{OAc} c_{2}$ act as precatalysts for the water oxidation reaction, since the acetato groups are easily replaced by water at $\mathrm{pH}=7$ generating the active catalysts, $\left\{\left[\mathrm{Ru}\left(\mathrm{H}_{2} \mathrm{O}\right)(\operatorname{trpy})\right]_{2}\left(\mu-\left[\mathrm{M}\left(\mathrm{H}_{2} \mathrm{O}\right)_{2}(\mathrm{bpp})_{2}\right]\right)\right\}^{4+}\left(\mathrm{M}=\mathrm{Co}^{\prime \prime}: \mathrm{Ru}_{2} \mathrm{Co}-\left(\mathrm{H}_{2} \mathrm{O}\right)_{4} ; \mathrm{M}=\mathrm{Mn}^{\prime \prime}: \mathrm{Ru}_{2} \mathrm{Mn}-\right.$ $\left.\left(\mathrm{H}_{2} \mathrm{O}\right)_{4}\right)$. The photochemical water oxidation reaction is studied using $\left[\mathrm{Ru}(\mathrm{bpy})_{3}\right]^{2+}$ as the photosensitizer and $\mathrm{Na}_{2} \mathrm{~S}_{2} \mathrm{O}_{8}$ as a sacrificial electron acceptor at $\mathrm{pH}=7$. The Co containing complex generates a TON of 50 in about 10 minutes $\left(\mathrm{TOF}_{\mathrm{i}}=0.21 \mathrm{~s}^{-1}\right.$ ), whereas the Mn containing complex only generates a TON of 8. The water oxidation reaction of $\mathrm{Ru}_{2} \mathrm{Co}-\left(\mathrm{H}_{2} \mathrm{O}\right)_{4}$ is further investigated using oxone as a sacrificial chemical oxidant at $\mathrm{pH}=7$. Labelled water oxidation experiments suggest that a nucleophilic attack mechanism is occurring at the Co site of the trinuclear complex with cooperative involvement of the two Ru sites, via electronic coupling through the $\mathrm{bpp}^{-}$bridging ligand and via neighboring hydrogen bonding.

Received 4th December 2015 Accepted 1st February 2016

DOI: $10.1039 / \mathrm{c} 5 \mathrm{sc} 04672 \mathrm{f}$

www.rsc.org/chemicalscience obtain so-called solar fuel (such as $\mathrm{H}_{2}$ ), mimicking natural photosynthesis. Water oxidation is the main reaction that occurs at the OEC-PSII, ${ }^{\mathbf{1 1}}$ yielding molecular oxygen, four protons and four electrons, which can later react further. The development of new water oxidation catalysts (WOCs) has been based mainly on mononuclear ${ }^{\mathbf{1 2}}$ and dinuclear ${ }^{\mathbf{1 3 , 1 4}} \mathrm{Ru}$ complexes containing polypyridilic ligands. However, recently, a number of Ir and first row transition metal complexes have also been reported to be able to oxidize water.,15,16

While mononuclear complexes are in general easier to prepare, targeted polynuclear complexes can present significant synthetic challenges. Nevertheless, polynuclear complexes containing bridging ligands that can electronically couple the metal centers can attain important benefits from the perspective of a WOC. For example, multiple electronically coupled redox active metal centers can cooperate during the four electron transfers needed for the water oxidation reaction. On the other hand, non-redox active centers can be of interest to exert electronic perturbation over the redox active center. ${ }^{17,18}$ They 
can also provide aqua/hydroxo ligands which, when strategically situated, can help to lower activation energies by hydrogen bonding with key active species bonded to the active metal, or even participate in $\mathrm{O}-\mathrm{O}$ bond formation, as has been proposed for the $\mathrm{Ca}-\mathrm{OH}_{2}$ moiety of the OEC-PSII on a number of occasions. ${ }^{19,20}$

With these considerations in mind, we undertook the preparation of heterotrinuclear complexes where all of the metal centers are redox active and possess aqua ligands, to favor the achievement of high oxidation states via Proton Coupled Electron Transfer (PCET). Herein, we report the synthesis, structural, spectroscopic and electrochemical characterization of a new family of heterotrinuclear complexes containing $\mathrm{Ru}$ and Co or Mn as metal centers, together with their capacity to oxidize water to dioxygen.

\section{Results and discussion}

\section{Synthesis and solid state structure}

The well-known Hbpp ligand is an asymmetric molecule which, once deprotonated, presents two equivalent coordination environments. The protonated ligand thus allows the preparation of mononuclear complexes that can be used as starting materials for the preparation of homo- ${ }^{21}$ or heterodinuclear, or heterotrinuclear $^{22}$ complexes. In the present report we use out$[\mathrm{Ru}(\mathrm{Cl})(\mathrm{Hbpp})(\operatorname{trpy})]^{+}$, out-0, as the starting material for the preparation of heterotrinuclear complexes containing redox active metals, as displayed in Scheme 1.

The pyrazolato proton of out-0 is removed using NaOMe as a base, and then $\mathrm{MnCl}_{2}$ or $\mathrm{CoCl}_{2}$ salts are used to react with the vacant coordination sites of the $\mathrm{bpp}^{-}$ligand, as shown in eqn (1) for the case of cobalt.

$$
\begin{aligned}
& \text { 2out- }[\mathrm{Ru}(\mathrm{Cl})(\mathrm{Hbpp})(\operatorname{trpy})]^{+}+2 \mathrm{MeO}^{-}+\mathrm{CoCl}_{2} \rightarrow \\
& \text { out-0 } \\
& \left\{[\mathrm{Ru}(\operatorname{trpy})]_{2}\left(\mu-\left[\mathrm{Co}(\mathrm{bpp})_{2}\right]\left[(\mu-\mathrm{Cl})_{2}\right]\right)\right\}^{2+}+2 \mathrm{Cl}^{-}+2 \mathrm{MeOH} \\
& \mathbf{R u}_{\mathbf{2}} \mathbf{C o -}-\mathbf{C l}_{2}
\end{aligned}
$$
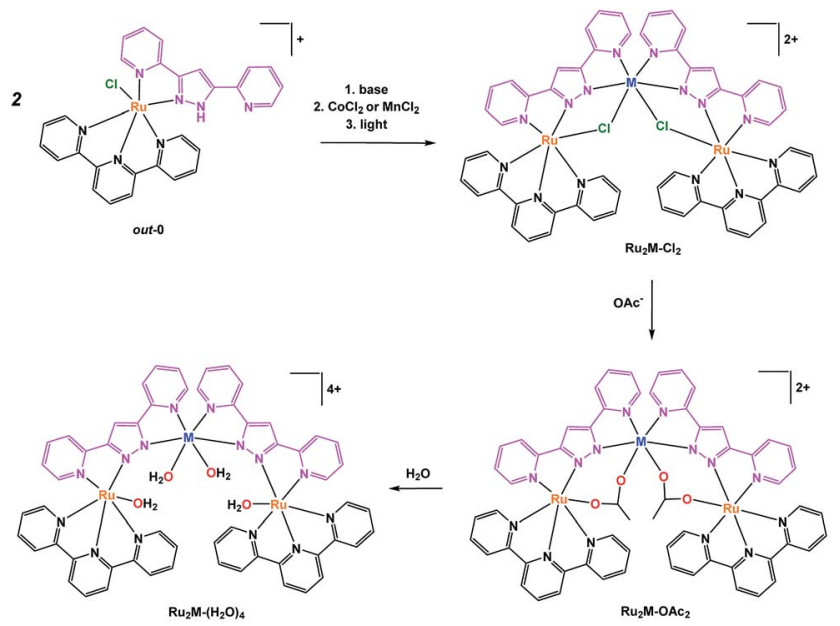

Scheme 1 Synthetic strategy followed for the preparation of trinuclear complexes and their labelling.
Complex $\mathbf{R} \mathbf{u}_{2} \mathbf{C o}-\mathbf{C l}_{\mathbf{2}}$ is obtained in $58 \%$ yield, whereas a $70 \%$ yield is obtained for $\mathbf{R} \mathbf{u}_{2} \mathbf{M n}-\mathbf{C l}_{\mathbf{2}}$ following a similar synthetic procedure. ${ }^{22}$ Treatment of these trinuclear complexes with sodium acetate at $75{ }^{\circ} \mathrm{C}$ in an acetone : water ( $5: 1)$ solution replaces the chlorido bridging ligands by the more labile acetato ligands, as indicated in the following equation.

$$
\begin{gathered}
\left\{[\operatorname{Ru}(\operatorname{trpy})]_{2}\left(\mu-\left[\mathrm{Co}(\mathrm{bpp})_{2}\right]\left[(\mu-\mathrm{Cl})_{2}\right]\right)\right\}^{2+}+2 \mathrm{OAc}^{-} \\
\mathbf{R u}_{\mathbf{2}} \mathbf{C o}-\mathbf{C l}_{\mathbf{2}} \\
\left\{[\mathrm{Ru}(\operatorname{trpy})]_{2}\left(\mu-\left[\mathrm{Co}(\mathrm{bpp})_{2}\right]\left[(\mu-\mathrm{OAc})_{2}\right]\right)\right\}^{2+}+2 \mathrm{Cl}^{-} \\
\mathbf{R u}_{\mathbf{2}} \mathbf{C o}-\mathbf{O A c}_{\mathbf{2}}
\end{gathered}
$$

Finally, substitution of the acetato bridges by monodentate aqua ligands leads to the formation of the corresponding tetraaqua complex in neutral pH (eqn (3)).

$$
\begin{gathered}
\left\{[\operatorname{Ru}(\operatorname{trpy})]_{2}\left(\mu-\left[\mathrm{Co}(\text { bpp })_{2}\right]\left[(\mu-\mathrm{OAc})_{2}\right]\right)\right\}^{2+}+4 \mathrm{H}_{2} \mathrm{O} \rightarrow \\
\mathbf{R u _ { 2 }} \mathbf{C o}-\mathbf{O A c}_{2}
\end{gathered}
$$

In contrast, under acidic conditions, the trinuclear complexes decompose to the corresponding mononuclear in$\left[\mathrm{Ru}(\mathrm{Hbpp})(\operatorname{trpy})\left(\mathrm{H}_{2} \mathrm{O}\right)\right]^{2+}$, in-1, and free $\mathrm{Co}(\mathrm{II})$ (Fig. S27†).

The synthetic strategies used for the preparation of $\mathbf{R u}_{2} \mathbf{M n}$ $\mathbf{O A c}_{2}$ and $\mathbf{R} \mathbf{u}_{2} \mathbf{M n}-\left(\mathbf{H}_{2} \mathbf{O}\right)_{\mathbf{4}}$ are analogous to those for the cobalt counterparts.

All of these new complexes have been characterized by analytic, spectroscopic or electrochemical techniques. Further, $\mathrm{X}$-ray diffraction analysis has been carried out for the $\mathrm{Mn}$ complexes, $\mathbf{R} \mathbf{u}_{\mathbf{2}} \mathbf{M n}-\mathbf{C l}_{\mathbf{2}}$ and $\mathbf{R u}_{\mathbf{2}} \mathbf{M n}-\mathbf{O A c} \mathbf{c}_{\mathbf{2}}$, and ORTEP views of their cationic moiety are presented in Fig. 1.

All the metal centers present pseudo-octahedral symmetry around the first coordination sphere. In the $\mathbf{R} \mathbf{u}_{\mathbf{2}} \mathbf{M n}-\mathbf{C l}_{\mathbf{2}}$ case, the ruthenium atoms are coordinated by five $\mathrm{N}$-atoms, three from a meridional trpy ligand and two from $\mathrm{bpp}^{-}$, while the sixth coordination position is occupied by a chlorido ligand. The manganese center is coordinated by the same two bridging chlorido moieties, in a cis fashion, and by the two chelating $\mathrm{bpp}^{-}$ligands. The "Mn(bpp $)_{2}$ " moiety can thus be considered as a bridge between the two Ru centers (see Fig. 1 and Scheme 1). A very similar structure is obtained for $\mathbf{R} \mathbf{u}_{2} \mathbf{M n}-\mathbf{O A} \mathbf{c}_{\mathbf{2}}$ where the bridging chlorido ligands have been substituted by bridging acetato ligands. For both structures, the bonding distances and angles presented by the $\mathrm{Ru}(\mathrm{II})$ and $\mathrm{Mn}$ (II) centers are unremarkable. $^{23,24}$

\section{Redox properties and UV-vis spectroscopy in organic solvents for $\mathrm{Ru}_{2} \mathrm{M}-\mathrm{OAc} \mathrm{c}_{2}$}

The cyclic voltammogram of $\mathbf{R} \mathbf{u}_{2} \mathbf{C o}-\mathbf{O A c} \mathbf{c}_{2}$ in $\mathrm{CH}_{3} \mathrm{CN}$ (Fig. 2) displays three successive reversible oxidation waves at $E_{1 / 2}=$ $0.70(\Delta E=75 \mathrm{mV}), 1.08(\Delta E=60 \mathrm{mV})$, and $1.22 \mathrm{~V}(\Delta E=60 \mathrm{mV})$, and one reversible reduction wave at $E_{1 / 2}=-1.23 \mathrm{~V}(\Delta E=80$ $\mathrm{mV}$ ). All the redox potentials in this work are reported $v s$. NHE. Each of the three oxidation processes corresponds to the 

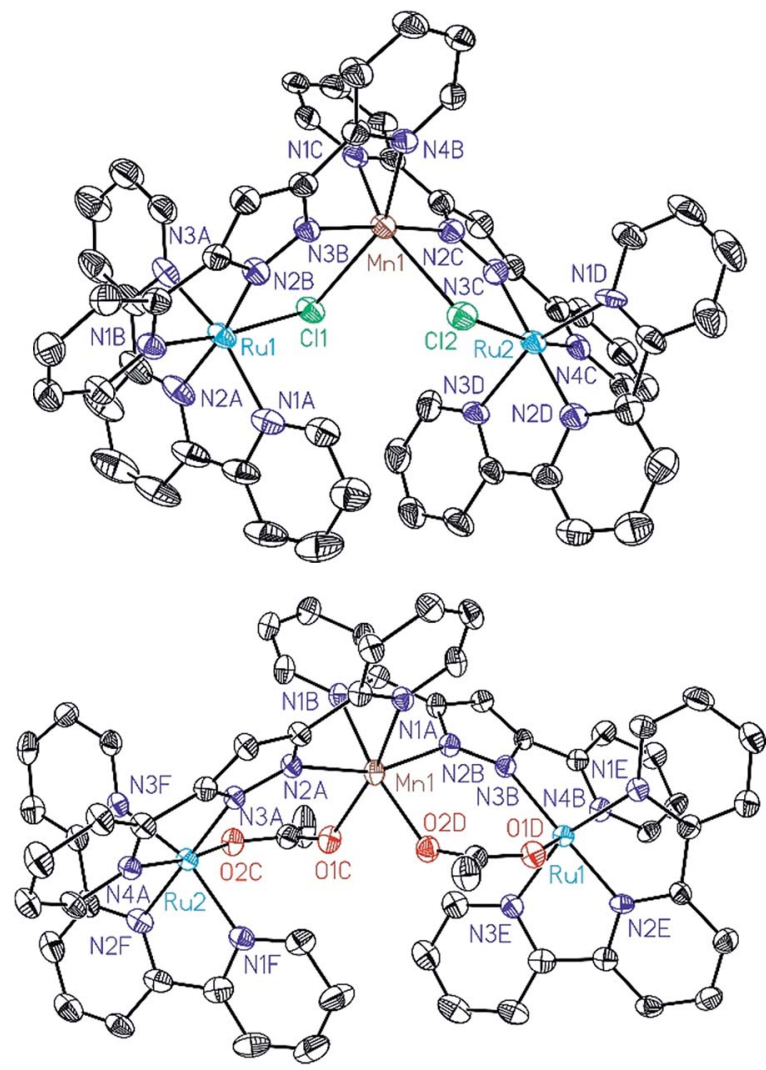

Fig. 1 ORTEP plots (50\% probability) for the cationic structures of complexes $\mathrm{Ru}_{2} \mathrm{Mn}-\mathrm{Cl}_{2}$ (top) and $\mathrm{Ru}_{2} \mathrm{Mn}-(\mathrm{OAc})_{2}$ (bottom). Hydrogen atoms have been omitted.
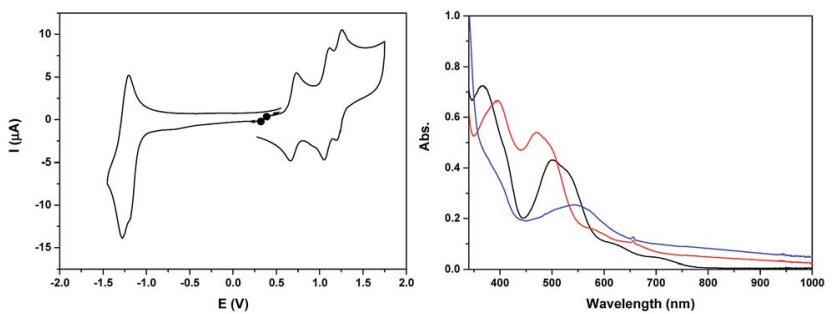

Fig. 2 (Left) Cyclic voltammogram of a $0.25 \mathrm{mM}$ solution of $\mathrm{Ru}_{2} \mathrm{Co}-$ $\mathrm{OAc}_{2}$ in $0.1 \mathrm{M}\left[\left(n \mathrm{Bu}_{4} \mathrm{~N}\right) \mathrm{ClO}_{4}\right]$ in $\mathrm{CH}_{3} \mathrm{CN}$, at a scan rate of $100 \mathrm{mV} \mathrm{s}^{-1}$. (Right) UV-visible absorption spectra of a $0.25 \mathrm{mM}$ solution of $\mathrm{Ru}_{2} \mathrm{Co}-$ $\mathrm{OAc}_{2}$ in $0.1 \mathrm{M}\left[\left(n \mathrm{Bu}_{4} \mathrm{~N}\right) \mathrm{ClO}_{4}\right]$ in $\mathrm{CH}_{3} \mathrm{CN}$, in oxidation states (black) $\mathrm{Ru}_{2}\left(\right.$ II)Co(II), (red) $\mathrm{Ru}_{2}\left(\right.$ II)Co(III) and (blue) $\mathrm{Ru}_{2}($ III)Co(III).

exchange of one electron per molecule of complex, as evidenced by rotating disk electrode experiments (Fig. S19†). The first process is assigned to the oxidation of the cobalt $\mathrm{Co}(\mathrm{III}) / \mathrm{Co}(\mathrm{II})$ and the last two to the oxidation of the two Ru sites, $\mathrm{Ru}_{2}(\mathrm{II}, \mathrm{III}) /$ $\mathrm{Ru}_{2}$ (II,II) and $\mathrm{Ru}_{2}(\mathrm{III}, \mathrm{III}) / \mathrm{Ru}_{2}(\mathrm{II}, \mathrm{III})$. The presence of two distinct one-electron redox processes, close in potential $\left(\Delta E_{1 / 2}=140\right.$ $\mathrm{mV}$ ), instead of a two-electron single wave, is in agreement with there being two identical electroactive centers in the molecule that can electronically communicate..$^{24}$ This is the case of the two Ru sites interacting through the conjugation of the bridging $\mathrm{bpp}^{-}$ligands and the acetato bridge via the central $\mathrm{Co}^{3+}$ core. The two electron reduction wave at $-1.23 \mathrm{~V}$ is assigned to the reduction of the terpyridine units of the $\mathrm{Ru}$ (II) centers. The shoulder observed at $-1.18 \mathrm{~V}$ indicates that the two terpyridine ligands are not fully equivalent, which is in accordance with there being weak electronic coupling between the two $\mathrm{Ru}$ subunits.

The two oxidized forms of the complex, $\mathrm{Ru}_{2}(\mathrm{II}) \mathrm{Co}(\mathrm{III})$ and $\mathrm{Ru}_{2}(\mathrm{III}) \mathrm{Co}$ (III) are stable in $\mathrm{CH}_{3} \mathrm{CN}$, as tested by successive electrolysis at $E=0.85 \mathrm{~V}$ and $E=1.40 \mathrm{~V}$, which consume, respectively, one and two electrons (Fig. S18†). Rotating disk electrode experiments confirm the quantitative formation of these species (Fig. S19†). The electrogenerated solutions have also been analyzed by UV-visible (Fig. 2) and EPR spectroscopy (Fig. 4, see below).

The three stable oxidation states, $\mathrm{Ru}_{2}$ (II) $\mathrm{Co}(\mathrm{II}), \mathrm{Ru}_{2}(\mathrm{II}) \mathrm{Co}(\mathrm{III})$ and $\mathrm{Ru}_{2}(\mathrm{III}) \mathrm{Co}(\mathrm{III})$, have distinct UV-visible signatures. The initial orange $\mathrm{Ru}_{2}(\mathrm{II}) \mathrm{Co}(\mathrm{II})$ solution exhibits two intense visible bands at 366 and $500 \mathrm{~nm}$ (with a shoulder at $530 \mathrm{~nm}$ ) and two less intense shoulders at 620 and $710 \mathrm{~nm}$. The oxidation of the central $\mathrm{Co}$ (II) unit into $\mathrm{Co}(\mathrm{III})$ leads to a shift of the intense visible bands to 396 and $473 \mathrm{~nm}$ (shoulder at $500 \mathrm{~nm}$ ) and of the two shoulders to 580 and $655 \mathrm{~nm}$. A more pronounced color change of the solution is observed when the two Ru(II) species are oxidized into $\mathrm{Ru}(\mathrm{III})$, as indicated by the replacement of all the previous visible bands by new ones at 390 (shoulder) and $545 \mathrm{~nm}$. An increase in absorption is also observed between 600 and $1000 \mathrm{~nm}$. As the more evident changes occur after the oxidation from $\mathrm{Ru}_{2}$ (II) $\mathrm{Co}$ (III) to $\mathrm{Ru}_{2}$ (III) $\mathrm{Co}$ (III), the intense visible absorption bands originate from the ruthenium units.

Back electrolysis of the final solution conducted at $0.35 \mathrm{~V}$ (three electrons exchanged) restores the initial complex, $\mathrm{Ru}_{2}(\mathrm{II})$ $\mathrm{Co}(\mathrm{II})$, quantitatively (Fig. S20 $\dagger$ ). This demonstrates the perfect stability of the different oxidation states of the trinuclear compound, and the reversibility of the processes.

The cyclic voltammogram of $\mathbf{R u}_{2} \mathbf{M n}-\mathbf{O A c}_{2}$ in $\mathbf{C H}_{3} \mathbf{C N}$ (Fig. 3 and S21 $\dagger$ ) also displays three successive one-electron reversible oxidation waves at $E_{1 / 2}=0.85 \mathrm{~V}(\Delta E=60 \mathrm{mV}), 0.96 \mathrm{~V}(\Delta E=70$ $\mathrm{mV})$ and $1.47 \mathrm{~V}(\Delta E=100 \mathrm{mV})$ at a scan rate of $50 \mathrm{mV} \mathrm{s}^{-1}$ and a reversible two-electron terpyridine-centered reduction wave at $E_{1 / 2}=-1.23 \mathrm{~V}(\Delta E=80 \mathrm{mV})$. The two first oxidation waves, very close in potential $\left(\Delta E_{1 / 2}=110 \mathrm{mV}\right)$, are thus assigned to
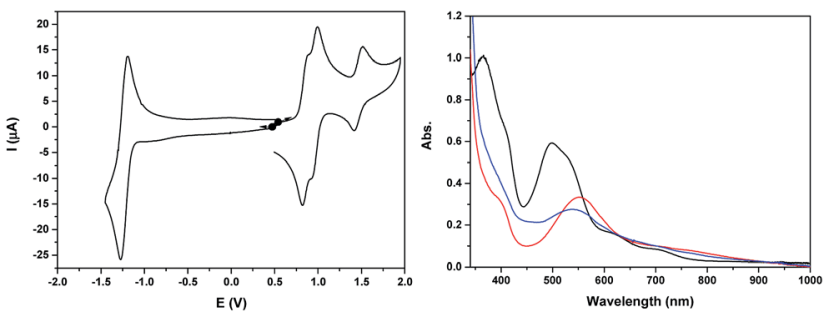

Fig. 3 (Left) Cyclic voltammogram of a $0.41 \mathrm{mM}$ solution of $\mathrm{Ru}_{2} \mathrm{Mn}-$ $\mathrm{OAc}_{2}$ in $0.1 \mathrm{M}\left[\left(n \mathrm{Bu}_{4} \mathrm{~N}\right) \mathrm{ClO}_{4}\right]$ in $\mathrm{CH}_{3} \mathrm{CN}$, at a scan rate of $50 \mathrm{mV} \mathrm{s}$. (Right) UV-visible absorption spectra of a $0.41 \mathrm{mM}$ solution of $\mathrm{Ru}_{2} \mathrm{Mn}-$ $\mathrm{OAc}_{2}$ in $0.1 \mathrm{M}\left[\left(n \mathrm{Bu}_{4} \mathrm{~N}\right) \mathrm{ClO}_{4}\right]$ in $\mathrm{CH}_{3} \mathrm{CN}$, in oxidation states, (black) $\mathrm{Ru}_{2}(\mathrm{II}) \mathrm{Mn}(\mathrm{I})$, (red) $\mathrm{Ru}_{2}(\mathrm{II}) \mathrm{Mn}(\mathrm{I})$ and (blue) $\mathrm{Ru}_{2}(\mathrm{II}) \mathrm{Mn}(\mathrm{II})$. 
the oxidation of the $\mathrm{Ru}$ sites, $\mathrm{Ru}_{2}$ (II,III)/ $\mathrm{Ru}_{2}$ (II,II) and $\mathrm{Ru}_{2}$ (III,III)/ $\mathrm{Ru}_{2}$ (II,III) and the last one to the Mn central unit, $\mathrm{Mn}(\mathrm{III}) / \mathrm{Mn}$ (II).

The stability of the two oxidized states, $\mathrm{Ru}_{2}$ (III)Mn(II) and $\mathrm{Ru}_{2}(\mathrm{III}) \mathrm{Mn}$ (III), has been evaluated by two successive electrolyses at $E=1.11 \mathrm{~V}$ and $1.69 \mathrm{~V}$. The first electrolysis at $1.11 \mathrm{~V}$ consumed two electrons per molecule of initial complex and lead to the quantitative formation of the $\mathrm{Ru}_{2}$ (III)Mn(II) species. An additional one electron oxidation carried out at $1.69 \mathrm{~V}$ leads to the formation of the fully oxidized form, $\mathrm{Ru}_{2}$ (III)Mn(III). At this stage, the presence of an additional reversible process at $E_{1 / 2}=$ $1.23 \mathrm{~V}$ with very small intensity should be pointed out, which is probably related to minor decomposition of the complex by decoordination of the Mn ion (less than 5\%, Fig. S21†). Indeed, the potential of this new process is similar to that of a $\mathrm{RuN}_{6}$ mononuclear complex such as in- $\left[\mathrm{Ru}(\mathrm{Hbpp})(\operatorname{trpy})\left(\mathrm{CH}_{3} \mathrm{CN}\right)\right]^{2+}$. Both electrolysis processes have been monitored by UV-vis and X-band EPR spectroscopy (Fig. 3 and 4, respectively).

The UV-vis absorption spectrum of $\mathbf{R u}_{2} \mathbf{M n}-\mathbf{O A c}_{2}$, with two intense visible bands at 365 and $497 \mathrm{~nm}$ (with a shoulder at 530 $\mathrm{nm}$ ) and two less intense shoulders at 620 and $710 \mathrm{~nm}$, is nearly identical to that of $\mathbf{R u}_{2} \mathbf{C o}-\mathbf{O A c}_{\mathbf{2}}$ (see Fig. $\mathrm{S} 9 \dagger$ for a comparison of the spectra). These observations confirm that the visible absorption bands originate mainly from the Ru units. Once the two $\mathrm{Ru}$ (II) units have been oxidized, formation of the $\mathrm{Ru}_{2}$ (III) $\mathrm{Mn}$ (II) species leads to significant changes with the replacement of the initial visible bands by new ones at 400 (shoulder) and 553 $\mathrm{nm}$ and two shoulders at 710 and $764 \mathrm{~nm}$. For the fully oxidized solution, the oxidation of the central Mn(II) unit into Mn(III) leads to minor changes, with a shift of the band at $553 \mathrm{~nm}$ to $538 \mathrm{~nm}$ and a small increase of the absorption around $450 \mathrm{~nm}$ (Fig. 3).

The initial reduced state of the complex $\mathbf{R} \mathbf{u}_{2} \mathbf{M n}-\mathbf{O A c _ { 2 }}$ is restored almost quantitatively by a back electrolysis of the final solution at $0.35 \mathrm{~V}$ (Fig. S22†).

\section{EPR properties}

The X-band EPR spectra of the initial and electrochemically oxidized solutions of $\mathbf{R u}_{2} \mathbf{C o}-\mathbf{O A c}_{2}$ have been recorded at low temperature (13 K) (Fig. 4). The initial solution of $\mathbf{R} \mathbf{u}_{2} \mathbf{C o}-\mathbf{O A c} \mathbf{c}_{\mathbf{2}}$ shows an EPR signal characteristic of a Co(II) ion $\left(d^{7}\right)$ in the high spin state $(S=3 / 2),{ }^{25}$ arising from the central $\mathrm{Co}$ (II) unit, as both $\mathrm{Ru}$ units $\left(\mathrm{Ru}(\mathrm{II}), \mathrm{d}^{6}\right)$ are diamagnetic and thus EPR silent. The
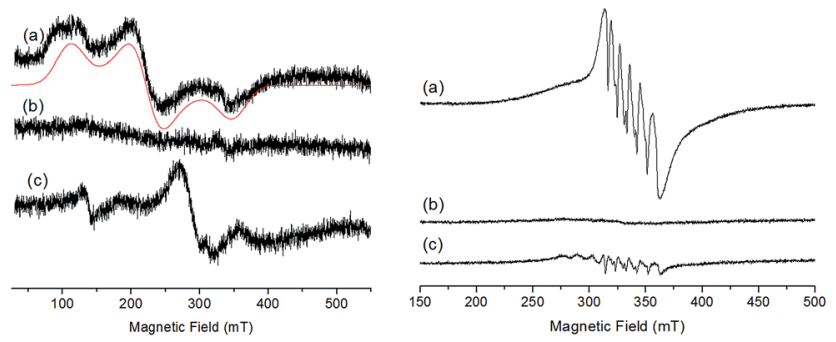

Fig. 4 (Left) $X$-band EPR spectra recorded at $13 \mathrm{~K}$ of a $0.25 \mathrm{mM}$ solution of $\mathrm{Ru}_{2} \mathrm{Co}-\mathrm{OAc}_{2}$ in $0.1 \mathrm{M}\left[\left(n \mathrm{Bu}_{4} \mathrm{~N}\right) \mathrm{ClO}_{4}\right]$ in $\mathrm{CH}_{3} \mathrm{CN}$, in oxidation states (a) $\mathrm{Ru}_{2}\left(\right.$ II)Co(॥), (b) $\mathrm{Ru}_{2}\left(\right.$ (I)Co(II) and (c) $\mathrm{Ru}_{2}($ (II)Co(II)) (black), and corresponding simulated spectra (red). (Right) X-band EPR at $100 \mathrm{~K}$ of a $0.41 \mathrm{mM}$ solution of $\mathrm{Ru}_{2} \mathrm{Mn}-\mathrm{OAc}_{2}$ in $0.1 \mathrm{M}\left[\left(n \mathrm{Bu}_{4} \mathrm{~N}\right) \mathrm{ClO}_{4}\right]$ in $\mathrm{CH}_{3} \mathrm{CN}$, in oxidation states (a) $\mathrm{Ru}_{2}(\mathrm{II}) \mathrm{Mn}(\mathrm{II}),\left(\right.$ b) $\mathrm{Ru}_{2}(\mathrm{II}) \mathrm{Mn}$ (II) and (c) $\mathrm{Ru}_{2}(\mathrm{III}) \mathrm{Mn}(\mathrm{III})$. analysis of high spin Co(II) centers is difficult because the zero field splitting (ZFS) energy is usually greater than the Zeeman interaction, leading to spectra insensitive to the magnitude of the axial term $(D)$ of the ZFS. Consequently, only the real $g$-values $(g$ real $)$ and the rhombicity ( $E / D$ ratio) of the system can be extracted from the simulation of the EPR spectra. Simulation of the experimental data provides the following spin-Hamiltonian parameters for the $M_{\mathrm{s}}=| \pm 1 / 2\rangle: g_{\text {real }}(x, y)=2.42, g_{\text {real }}(z)=$ 2.31 , and $E / D=0.23$.

After the one-electron oxidation into $\mathrm{Ru}_{2}(\mathrm{II}) \mathrm{Co}(\mathrm{III})$, the solution becomes EPR silent, in accordance with the formation of the low-spin $\mathrm{Co}(\mathrm{III})$ species $\left(\mathrm{d}^{6}\right)(S=0){ }^{26}$

The EPR spectrum of the fully oxidized solution of $\mathrm{Ru}_{2}$ (III) Co(III) displays two features ascribable to an effective $S=1$ spin state which results from a magnetic interaction between two $S=$ $1 / 2$ spin states located on the $\mathrm{Ru}(\mathrm{III})$ metals. The characteristic rhombic signature of the low spin $\mathrm{Ru}(\mathrm{III}) S=1 / 2$ spin state $\left(\mathrm{d}^{5}\right)$ between 210 and $360 \mathrm{mT}$ is retained in the spectrum. ${ }^{27,28}$ A weak half-field EPR line is also observed at $139 \mathrm{mT}$, which is consistent with the $S=1$ spin state induced by the magnetic interaction of two Ru(III) ions. EPR spectra with similar features have been previously reported for magnetically coupled dinuclear $\mathrm{Ru}(\mathrm{III})-\mathrm{Ru}(\mathrm{III})$ complexes. $^{28}$

The EPR signal of the initial $\mathbf{R u}_{2} \mathbf{M n}-\mathbf{O A c}_{\mathbf{2}}$ solution at $100 \mathrm{~K}$ exhibits a 6-line signal characteristic of a high-spin Mn(II) ion $\left(3 \mathrm{~d}^{5}, S=5 / 2\right)$, related to the central Mn(II) unit of the complex (Fig. 4). ${ }^{27}$ This signal fully disappears after the oxidation of the two diamagnetic $\mathrm{Ru}(\mathrm{II})$ units into $\mathrm{Ru}(\mathrm{III})$. Although an EPR signal is expected for a magnetically coupled system involving two $\operatorname{Ru}(\mathrm{III})(S=1 / 2)$ ions and one $\mathrm{Mn}$ (II) $(S=5 / 2)$, no EPR signal was detected regardless of temperature (from $13 \mathrm{~K}$ to $200 \mathrm{~K}$ ), presumably due to fast relaxation. The fully oxidized solution of $\mathrm{Ru}_{2}$ (III)Mn(III) is also EPR silent, which is in agreement with there being magnetic coupling between the two $\operatorname{Ru}(\mathrm{III})(S=1 / 2)$ and the $\mathrm{Mn}(\mathrm{III})\left(\mathrm{d}^{4}, S=2\right)$ ions, which must produce a integer spin ground state. The low-intensity signals observed around $g=2$ are attributed to some decomposition of the trinuclear $\mathrm{Ru}_{2}$ (III)Mn(III) (OAc) $)_{2}$ complex (less than $5 \%$, as shown by electrochemistry) into "free" $\mathrm{Mn}$ (II) (six line feature centered at $g=2.0$, $339 \mathrm{mT})$ and the mononuclear $\left[\mathrm{Ru}^{\mathrm{III}}(\mathrm{bpp})(\operatorname{trpy})\left(\mathrm{CH}_{3} \mathrm{CN}\right)\right]^{3+}$ complex $(S=1 / 2)$ (the two features at a low magnetic field compared to the six line feature).

\section{Magnetic properties}

Magnetic susceptibility measurements were performed under a constant magnetic field of $5000 \mathrm{Oe}$, in the temperature range of 2-300 K. Variable field reduced magnetization at $2 \mathrm{~K}$ was performed for all complexes. Isofield variable temperature reduced magnetization measurements were also performed under various fields. These experiments served as criteria of purity, since this chemistry often leads to the formation of small impurities of $\mathrm{Ru}(0)$ particles that become very visible when the magnetic properties are examined.

The constant field and variable temperature magnetic susceptibility results are represented in the form of $\chi T$ vs. $T$ curves (where $\chi$ is the molar paramagnetic susceptibility) (Fig. 5). 
The $\chi T$ products for the complexes $\mathbf{R u}_{\mathbf{2}} \mathbf{C o}-\mathbf{C l}_{\mathbf{2}}$ and $\mathbf{R} \mathbf{u}_{\mathbf{2}} \mathbf{C o}-$ $\mathbf{O A c}_{2}$ are, at $300 \mathrm{~K}, 3.44$ and $2.96 \mathrm{~cm}^{3} \mathrm{~K} \mathrm{~mol}^{-1}$, respectively, which are significantly higher than the expected values for spinonly $\mathrm{Co}$ (II) ions (calculated as $1.875 \mathrm{~cm}^{3} \mathrm{~K} \mathrm{~mol}^{-1}$ for $g=2.0$ and $S=3 / 2$ ). This product decreases with an increasing rate as the temperature declines. Both observations are accounted for by the fact that octahedral high spin Co(II) exhibits an orbital angular momentum $(L=1)$ in addition to the spin state $(S=3 / 2)$. This causes the observation of an effective $g$ value that is much higher than expected for a spin only system (here calculated as 2.51 and 2.71, respectively). The differences between both ions are caused by their slightly differing coordination geometries, as well as the varying ligand field strength of some of the donors. ${ }^{29}$ The depopulation of the $J$ multiplets arising from the spin-orbit coupling explains the decline of $\chi T$ upon cooling. The reduced magnetization curves measured at $2 \mathrm{~K}$ (Fig. S25 †) saturate for both compounds at values lower than expected for an $S=3 / 2$ system. This is because at such a low temperature, only the lowest $J$ multiplet is populated. Isofield magnetization curves (at temperatures below $7 \mathrm{~K}$ and under several fields) produce the same saturation values and show quasi-superposition of the various curves (Fig. S26†). This shows that the anisotropy of these low energy states is very small. These results are consistent with the above characterization and with the interpretation of the EPR results.

At $300 \mathrm{~K}$, the $\chi T$ products for the complexes $\mathbf{R} \mathbf{u}_{\mathbf{2}} \mathbf{M n}-\mathbf{C l}_{\mathbf{2}}$ and $\mathbf{R u}_{2} \mathbf{M n}-\mathbf{O A c}_{2}$ are almost identical; 4.43 and $4.45 \mathrm{~cm}^{3} \mathrm{~K} \mathrm{~mol}^{-1}$, respectively, which correspond to the expected spin-only value for an isolated $\mathrm{Mn}$ (II) center with $S=5 / 2$ spin state and $g=2.01$ and 2.02, respectively, consistent with the EPR and electrochemical results. This value stays nearly constant until around 5 $\mathrm{K}$, where a decline down to 3.98 and $4.04 \mathrm{~cm}^{3} \mathrm{~K} \mathrm{~mol}^{-1}$ at $2 \mathrm{~K}$, respectively, is observed. The low temperature decline can be due to a small value of ZFS, or weak antiferromagnetic intermolecular interactions. The variable field reduced magnetization curves, measured at $2 \mathrm{~K}$ (Fig. S23 $\dagger$ ), and the isofield magnetization curves (Fig. S24 $\dagger$ ) are the result of $\mathrm{Mn}$ (II) saturating near 5 Bohr magneton, and this is consistent with the above results. The fact that the isofield lines superimpose with each other for the various fields employed confirms that the amount of ZFS is very small for both complexes.

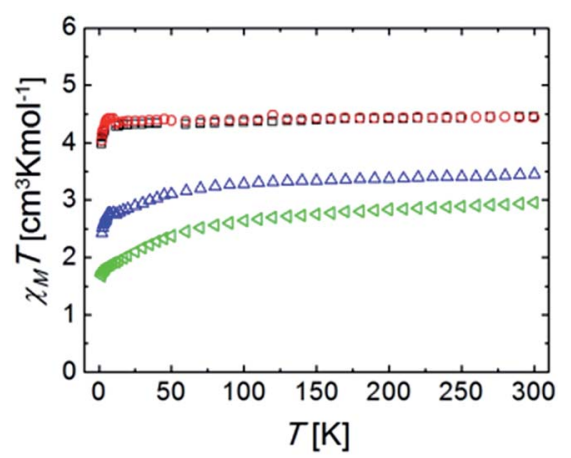

Fig. 5 Plots of $\chi T$ vs. $T$ ( $\chi$ is the molar paramagnetic susceptibility) for complexes (blue) $\mathrm{Ru}_{2} \mathrm{Co}-\mathrm{Cl}_{2}$, (red) $\mathrm{Ru}_{2} \mathrm{Mn}-\mathrm{Cl}_{2}$, (green) $\mathrm{Ru}_{2} \mathrm{Co}-\mathrm{OAc}_{2}$, and (black) $\mathrm{Ru}_{2} \mathrm{Mn}-\mathrm{OAc}_{2}$, under a constant magnetic field of $5000 \mathrm{Oe}$.

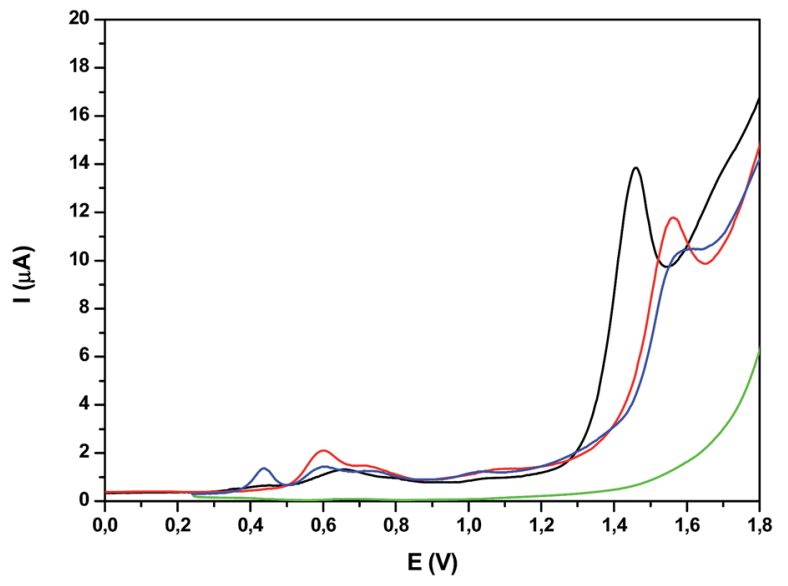

Fig. 6 DPV of (black) $\mathrm{Ru}_{2} \mathrm{Co}-\left(\mathrm{H}_{2} \mathrm{O}\right)_{4}$, (red) $\mathrm{Ru}_{2} \mathrm{Mn}-\left(\mathrm{H}_{2} \mathrm{O}\right)_{4}$, (blue) in-1 and (green) blank in a $\mathrm{pH}=7.0(50 \mathrm{mM})$ phosphate buffer solution and $\mathrm{CF}_{3} \mathrm{CH}_{2} \mathrm{OH}$ mixture $(19: 1)$.

\section{Redox properties in aqueous solutions}

The redox properties of the trinuclear complexes $\mathbf{R u _ { 2 }} \mathbf{C o}-\left(\mathbf{H}_{2} \mathbf{O}\right)_{4}$ and $\mathbf{R} \mathbf{u}_{2} \mathbf{M n}-\left(\mathbf{H}_{2} \mathbf{O}\right)_{4}$ were investigated by means of CV and DPV in a mixture of a $\mathrm{pH}=7.0$ phosphate buffer $(50 \mathrm{mM})$ and $\mathrm{CF}_{3} \mathrm{CH}_{2} \mathrm{OH}(19: 1)$, the use of the latter forced by the poor solubility of the complexes in water. While very nicely defined waves were observed in organic solvents for their acetato counterparts as shown previously, in aqueous solution, the waves are very wide (Fig. S28†). Nevertheless, the DPVs in Fig. 6 allow the observation of three faradaic processes situated at approximately 0.6, 0.7 and $1.0 \mathrm{~V}$ for both $\mathbf{R u}_{2} \mathbf{C o}-\left(\mathbf{H}_{2} \mathbf{O}\right)_{4}$ and $\mathbf{R} \mathbf{u}_{2} \mathbf{M n}-\left(\mathbf{H}_{2} \mathbf{O}\right)_{4}$, which are plotted together with the mononuclear aqua complex in-1 for comparative purposes. However, the most important feature is the large electrocatalytic wave displayed by these complexes, starting at $1.3 \mathrm{~V}$ for $\mathbf{R u}_{2} \mathbf{C o}-$ $\left(\mathbf{H}_{2} \mathbf{O}\right)_{4}$ and at around 1.5 V for $\mathbf{R u _ { 2 }} \mathbf{M n}-\left(\mathbf{H}_{2} \mathbf{O}\right)_{4}$ and $\boldsymbol{i n - 1}$, which is associated to water oxidation catalysis.

\section{Water oxidation catalysis}

Photochemically driven water oxidation catalysis has been carried out through the photogeneration of $\left[\mathrm{Ru}(\mathrm{bpy})_{3}\right]^{3+}$ as a chemical oxidant using persulfate as a sacrificial electron acceptor (eqn (4)-(6)).

$$
\begin{gathered}
{\left[\mathrm{Ru}^{\mathrm{II}}(\mathrm{bpy})_{3}\right]^{2+}+h \nu \rightarrow\left[\mathrm{Ru}^{\mathrm{II}}(\mathrm{bpy})_{3}\right]^{2+*}} \\
{\left[\mathrm{Ru}^{\mathrm{II}}(\mathrm{bpy})_{3}\right]^{2+} *+\mathrm{S}_{2} \mathrm{O}_{8}{ }^{2-} \rightarrow\left[\mathrm{Ru}^{\mathrm{III}}(\mathrm{bpy})_{3}\right]^{3+}+\mathrm{SO}_{4}{ }^{2-}+\mathrm{SO}_{4}{ }^{-}} \\
{\left[\mathrm{Ru}^{\mathrm{II}}(\mathrm{bpy})_{3}\right]^{2+}+\mathrm{SO}_{4}{ }^{-\cdot} \rightarrow\left[\mathrm{Ru}^{\mathrm{III}}(\mathrm{bpy})_{3}\right]^{3+}+\mathrm{SO}_{4}{ }^{2-}}
\end{gathered}
$$

The oxygen generation profile as a function of time is presented in Fig. 7 for the systems Cat $50 \mu \mathrm{M} /\left[\mathrm{Ru}(\mathrm{bpy})_{3}\right]^{2+} 0.5 \mathrm{mM} /$ $\mathrm{Na}_{2} \mathrm{~S}_{2} \mathrm{O}_{8} 20 \mathrm{mM} / \mathrm{pH}=7.0$ (50 mM phosphate buffer), with a total volume of $2.0 \mathrm{~mL}\left(\mathrm{H}_{2} \mathrm{O}: \mathrm{CF}_{3} \mathrm{CH}_{2} \mathrm{OH}=19: 1\right)$ using a 300 $\mathrm{W}$ xenon lamp with a band pass filter of $440 \mathrm{~nm}$, thermostated at $298 \mathrm{~K}$. Under these conditions, $\mathbf{R u}_{\mathbf{2}} \mathbf{C o}-\left(\mathbf{H}_{\mathbf{2}} \mathbf{O}\right)_{\mathbf{4}}$ generates a TON of 50 in about 10 minutes $\left(\mathrm{TOF}_{\mathrm{i}}=0.21 \mathrm{~s}^{-1}\right)$ whereas 


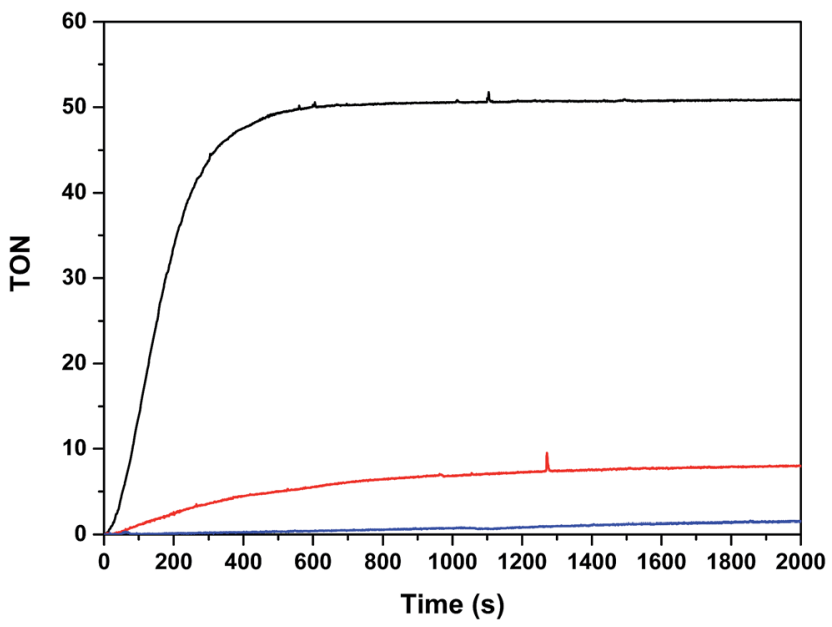

Fig. 7 Photochemically induced oxidation of $\mathrm{Ru}_{2} \mathrm{Co}-\left(\mathrm{H}_{2} \mathrm{O}\right)_{4}$ (black), $\mathrm{Ru}_{2} \mathrm{Mn}-\left(\mathrm{H}_{2} \mathrm{O}\right)_{4}$ (red) and in-1 (blue). Reaction conditions: [catalyst] = $50 \mu \mathrm{M},\left[\left[\mathrm{Ru}(\mathrm{bpy})_{3}\right]\left(\mathrm{ClO}_{4}\right)_{2}\right]=0.5 \mathrm{mM} ;\left[\mathrm{Na}_{2} \mathrm{~S}_{2} \mathrm{O}_{8}\right]=20 \mathrm{mM}$; total volume $=2 \mathrm{~mL}$ in a $\mathrm{pH}=7.0(50 \mathrm{mM})$ phosphate buffer solution and $\mathrm{CF}_{3}$ $\mathrm{CH}_{2} \mathrm{OH}$ mixture (19:1). A $300 \mathrm{~W}$ xenon lamp was used to illuminate the sample through a band pass filter of $440 \mathrm{~nm}$ at $298 \mathrm{~K}$. The $\mathrm{O}_{2}$ yields based on persulfate are: $25 \%, 4 \%$ and $<1 \%$, respectively, for $\mathrm{Ru}_{2} \mathrm{Co}-$ $\left(\mathrm{H}_{2} \mathrm{O}\right)_{4}, \mathrm{Ru}_{2} \mathrm{Mn}-\left(\mathrm{H}_{2} \mathrm{O}\right)_{4}$ and in-1.

$\mathbf{R} \mathbf{u}_{2} \mathbf{M n}-\left(\mathbf{H}_{2} \mathbf{O}\right)_{4}$ only generates a TON of 8 and the mononuclear complex in-1 does not generate any molecular oxygen within this time frame. These results are consistent with the electrochemical analysis, as the potentials for catalysis for $\mathbf{R u}_{2} \mathbf{M n}$ $\left(\mathrm{H}_{2} \mathrm{O}\right)_{\mathbf{4}}$ and $\mathbf{i n - 1}$ are too high for efficient catalysis, given the fact that the $\mathrm{Ru}(\mathrm{III}) / \mathrm{Ru}(\mathrm{II})$ potential for $\left[\mathrm{Ru}(\mathrm{bpy})_{3}\right]^{2+/ 3+}$ is $E_{1 / 2}=1.26 \mathrm{~V}$.

In light of the good results obtained in the photoactivated experiment, water oxidation catalysis with $\mathbf{R} \mathbf{u}_{2} \mathbf{C o}-\left(\mathbf{H}_{2} \mathbf{O}\right)_{4}$, and with the mononuclear in-1 for comparison, was also investigated using oxone $\left(\mathrm{KHSO}_{5}\right)$ as a chemical oxidant. The oxygen evolution profiles as a function of time are presented in Fig. 8. The Co containing complex generates $1.0 \mu \mathrm{mol}$ of oxygen $(0.41$ $\mu \mathrm{mol}$ are subtracted due to the activity of the blank under the same conditions) that correspond to a TON of about 13 .

Labelling experiments using $\mathrm{H}_{2}{ }^{18} \mathrm{O}$ were also carried out in order to extract mechanistic information regarding the $\mathrm{O}-\mathrm{O}$ bond formation event when using oxone as a chemical oxidant. The $\mathrm{O}_{2}$ 36/34/32 isotope ratio was followed by on-line Mass spectrometry. Two different degrees of $\mathrm{H}_{2} \mathrm{O}$ labelling were employed, and the results obtained are shown in Fig. 8.

For discussion of the mechanism, we consider first the experiment with $97 \% \mathrm{H}_{2}{ }^{18} \mathrm{O}$, and then test our hypothesis on the data obtained from the experiment with $15 \% \mathrm{H}_{2}{ }^{18} \mathrm{O}$. However, before making a hypothesis on the mechanism of oxygen evolution, it is paramount to obtain information on the labeling state of the system at the moment of the oxygen evolving event.

(a). Raman experiments carried out under the same conditions as the water oxidation labelling experiments showed that no ${ }^{18} \mathrm{O}$ exchange occurs at all between water and oxone for at least $10 \mathrm{~h}$ (Fig. S30†). ${ }^{30}$

(b). Substitution reactions of aqua ligands at low oxidation states (II) for $\mathrm{Ru}$ and Co complexes occur rapidly. As the
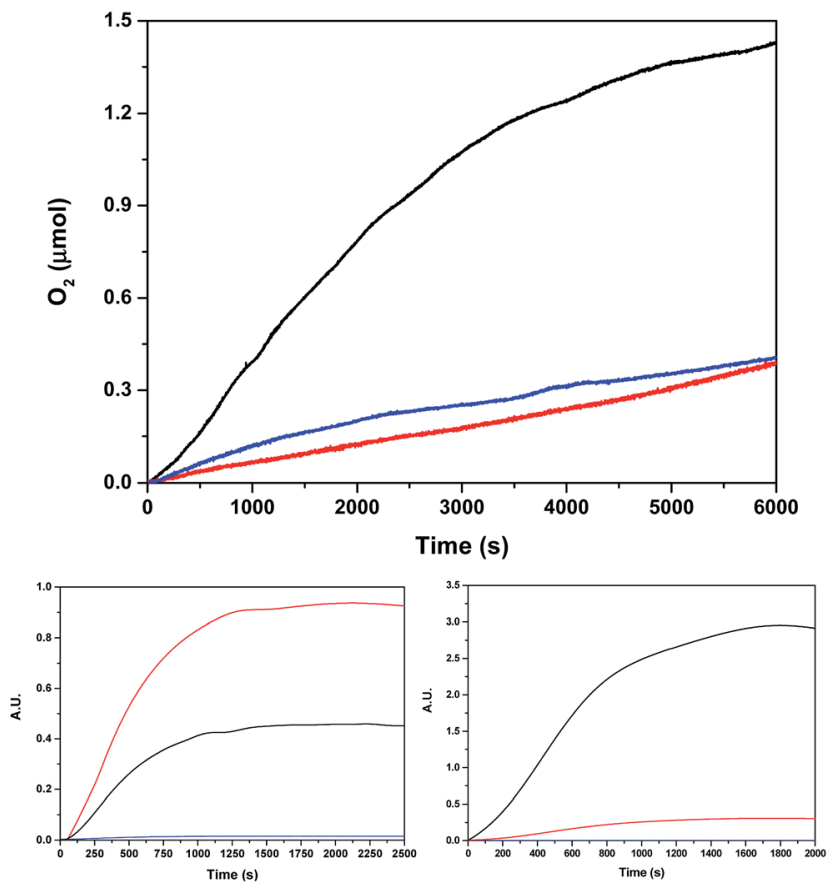

Fig. 8 (Top) Oxygen evolution profile using oxone $(4.7 \mathrm{mM})$ as a chemical oxidant for $40 \mu \mathrm{M} \mathrm{Ru} \mathrm{u}_{2} \mathrm{Co}-\left(\mathrm{H}_{2} \mathrm{O}\right)_{4}$ (black), $80 \mu \mathrm{M}$ in-1 (blue) and a blank without catalyst (red), using a $\mathrm{pH}=7.0(50 \mathrm{mM})$ phosphate buffer up to a total volume of $2.0 \mathrm{~mL}\left(\mathrm{H}_{2} \mathrm{O}: \mathrm{CF}_{3} \mathrm{CH}_{2} \mathrm{OH}=19: 1\right)$ in a $298 \mathrm{~K}$ thermostated cell. The $\mathrm{O}_{2}$ yields based on oxone for $\mathrm{Ru}_{2} \mathrm{Co}-$ $\left(\mathrm{H}_{2} \mathrm{O}\right)_{4}$ and in-1 are: $21 \%$ and $<1 \%$, respectively. (Bottom) Isotopic oxygen generation profile monitored by on-line $\mathrm{MS}$ for $\mathrm{Ru}_{2} \mathrm{Co}-\left(\mathrm{H}_{2} \mathrm{O}\right)_{4}$ using oxone in the same conditions. Bottom left using $97 \% \mathrm{H}_{2}{ }^{18} \mathrm{O}$, and bottom right using $15 \% \mathrm{H}_{2}{ }^{18} \mathrm{O}$. Color code: black ${ }^{32} \mathrm{O}_{2}$, red ${ }^{34} \mathrm{O}_{2}$, blue ${ }^{36} \mathrm{O}_{2}$.

precatalyst presents all acetate bridge ligands, we can assume that all the aqua ligands are initially present as $\mathrm{H}_{2}{ }^{18} \mathrm{O}$.

(c). Peroxide oxidations of Ru-aqua polypyridyl complexes occur through dehydrogenation pathways. ${ }^{31}$ Thus, oxone will react with low oxidation states of Ru-aqua as follows (auxiliary ligands not shown):

$$
\begin{aligned}
\mathrm{Ru}^{\mathrm{II}}-{ }^{18} \mathrm{OH}_{2}+\left[\mathrm{HO}-\mathrm{S}(\mathrm{O})_{2}(\mathrm{OO})\right]^{-} \rightarrow & \mathrm{Ru}^{\mathrm{IV}}={ }^{18} \mathrm{O}+\mathrm{H}_{2} \mathrm{O} \\
& +\mathrm{HSO}_{4}{ }^{-}
\end{aligned}
$$

(d). Oxidation of first row transition metals, particularly iron and cobalt polyridylic complexes, with peroxides occurs primarily via nucleophilic substitution..$^{32-34}$

$$
\begin{aligned}
& \mathrm{Co}^{\mathrm{II}-}{ }^{18} \mathrm{OH}_{2}+\left[\mathrm{HO}-\mathrm{S}(\mathrm{O})_{2}(\mathrm{OO})\right]^{-} \rightarrow \mathrm{Co}{ }^{\mathrm{II}}-\mathrm{OO}-\mathrm{S}(\mathrm{O})_{2}(\mathrm{OH}) \\
&+\mathrm{H}_{2} \mathrm{O}^{18} \\
& \mathrm{Co}^{\mathrm{II}}-\mathrm{OO}-\mathrm{S}(\mathrm{O})_{2}(\mathrm{OH}) \rightarrow \mathrm{Co}^{\mathrm{IV}}=\mathrm{O}+\mathrm{HSO}_{4}{ }^{-}
\end{aligned}
$$

(e). Tautomeric equilibrium between the oxo-hydroxo complexes, as described in eqn (10), would produce labelling scrambling, as has been earlier proposed for related complexes. ${ }^{35}$

$$
\mathrm{Co}^{\mathrm{IV}}\left({ }^{18} \mathrm{O}\right)(\mathrm{OH}) \rightleftharpoons \mathrm{Co}^{\mathrm{IV}}(\mathrm{O})\left({ }^{18} \mathrm{OH}\right)
$$




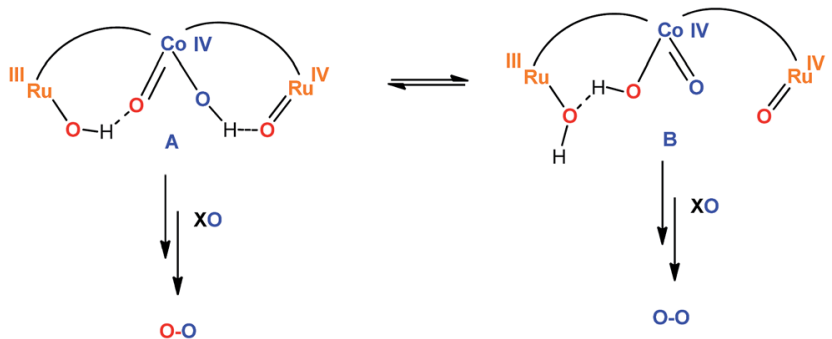

Scheme 2 Fast tautomeric equilibrium proposed for the active species of the trinuclear $\mathrm{Ru}_{2} \mathrm{Co}-\left(\mathrm{H}_{2} \mathrm{O}\right)_{4}$ complex just before the $\mathrm{O}-\mathrm{O}$ bond formation step. The bpp-ligand is represented by an arc and the trpy ligands are omitted for clarity purposes. XO represents the oxidant oxone $\left(\mathrm{KHSO}_{5}\right)$. The blue oxygens are ${ }^{16} \mathrm{O}$ and the red oxygens are ${ }^{18} \mathrm{O}$.

For the $\mathbf{R} \mathbf{u}_{2} \mathbf{C o}-\left(\mathbf{H}_{2} \mathbf{O}\right)_{4}$ complex, this situation at the oxygen evolving event is described in the top section of Scheme 2. This assumes that for $100 \% \mathrm{H}_{2}{ }^{18} \mathrm{O}$ labeling at oxidation state II, all the aqua groups are exchanged. For the $\mathrm{Ru}$ center reaching high oxidation states with non-labeled oxone, $\left[\mathrm{Ru}(\mathrm{IV})={ }^{18} \mathrm{O}\right]$ will be produced with $100 \%{ }^{18} \mathrm{O}$ labeling. However, for the cobalt center, a mixed labeled $\left[\mathrm{Co}(\mathrm{Iv})\left({ }^{16} \mathrm{O}\right)\left({ }^{18} \mathrm{OH}\right)\right]$ will be generated because of the nucleophilic attack mechanism mentioned above.

At this point, the following conclusions are extrapolated from the oxygen data shown in Fig. 8.

(1). The practically negligible amount of ${ }^{36} \mathrm{O}_{2}$ in the $97 \%$ $\mathrm{H}_{2}{ }^{18} \mathrm{O}$ experiment indicates the inexistence of intramolecular pathways between the $\mathrm{Ru}=\mathrm{O}$ and $\mathrm{Co}=\mathrm{O}$ moieties. In addition, it also precludes the existence of bimolecular pathways involving only the $\mathrm{Ru}=\mathrm{O}$ groups. On the other hand, potential bimolecular pathways involving only Co centers are sterically highly disfavorable.

(2). The mononuclear complex in-1 does not generate sufficient oxygen to be significant under the applied conditions and thus the inexistence of $\mathrm{O}_{2}$ coming independently from $\mathrm{Ru}$-aqua/ Ru-oxo moieties is ruled out.

(3). Cis $\mathrm{O}-\mathrm{O}$ coupling within the same Co metal center would be compatible with the ratios of isotopic labelling obtained, although this mechanism has been discarded based on DFT in a number of examples. ${ }^{36,37}$

(4). The 97\% labelling experiment (Fig. 8 and S31†) is consistent with the existence of a very fast tautomeric equilibrium where species A and B exist in a $2: 1$ ratio respectively (see Scheme 2). The origin of the higher stabilization of species A is proposed to come from the higher hydrogen bond capacity of isomer A with regard to that of $\mathrm{B}$. Oxidation states of $\mathrm{Ru}$ and $\mathrm{Co}$ are tentatively assigned from the apparent removal of 4/5 electrons from the oxidation state II,II,II, as judged from the electrocatalytic wave displayed by the complex. Assuming this equilibrium, the reaction of oxone (XO) with $\mathrm{A}$ and $\mathrm{B}$ would generate molecular oxygen with a ratio of isotopes of ${ }^{34} \mathrm{O}_{2} /{ }^{32} \mathrm{O}_{2}$ $=2 / 1$, which is what is found experimentally.

(5). Finally, changing the ratio of labelled water to $15 \%{ }^{18} \mathrm{O}$ (Fig. 8 and $\mathrm{S} 31 \dagger$ ), will generate molecular oxygen with a ratio of ${ }^{34} \mathrm{O}_{2} /{ }^{32} \mathrm{O}_{2}=1 / 9$. Experimentally, we obtained a ratio of $1 / 10$, which is in very good agreement with the proposed mechanism.
Overall, the labelling experiments carried out together with the rest of the electrochemical and spectroscopic properties are in agreement with the presence of a water nucleophilic attack (WNA) mechanism occurring at the Co site of the trinuclear complex, with cooperative interaction of the two $\mathrm{Ru}$ sites via electronic coupling through the $\mathrm{bpp}^{-}$bridging ligand and via neighboring hydrogen bonding.

It is worth mentioning that in our previous work with related dinuclear $\mathrm{Ru}^{21}$ and $\mathrm{Co}^{3}$ complexes containing the Hbpp ligand, namely $\left\{\left[\mathrm{M}\left(\mathrm{H}_{2} \mathrm{O}\right)(\text { trpy })\right]_{2} \mu-[(\mathrm{bpp})\}^{3+}(\mathrm{M}=\mathrm{Ru}\right.$ or $\mathrm{Co})$, the $\mathrm{O}-\mathrm{O}$ bond formation occurred via an intramolecular mechanism (I2M). ${ }^{38}$ However, with the new trinuclear complexes described here, given the new substantially different geometries and electronic interactions between the metal centers, the mechanism changes to a WNA.

\section{Conclusions}

We have prepared and isolated a family of trinuclear complexes, $\mathrm{Ru}_{2} \mathrm{M}-\mathrm{X}_{2}\left(\mathrm{M}=\mathrm{Co}\right.$ or $\mathrm{Mn} ; \mathrm{X}=\mathrm{Cl}^{-}$or $\left.\mathrm{OAc}^{-}\right)$, where the central Co or $\mathrm{Mn}$ atom, together with two $\mathrm{bpp}^{-}$ligands, acts as a bridge between the two external $\mathrm{Ru}$ moieties. These complexes have been characterized in the solid state by X-ray diffraction analysis and by magnetic measurements. In solution they have been characterized by spectroscopic (EPR, UV-vis) and by electrochemical (CV, DPV) techniques. Overall, all these experiments for the chlorido or acetato bridge complexes show the presence of a relatively weak electronic coupling between the metal centers, transmitted through the bridging ligands. In addition, it is very interesting to see how the redox pattern radically changes from the $\mathrm{Mn}$ complexes with regards to the Co complexes manifesting the intrinsically different electronic properties of the two transition metals. In aqueous acidic media the trinuclear complexes revert to their $\mathrm{Ru}$ mononuclear counterparts and free $\mathrm{Co}$ (II) or $\mathrm{Mn}$ (II). However at $\mathrm{pH}=7.0$ the integrity of the complex is fully retained. Of particularly interest is the heterotrinuclear $\mathbf{R} \mathbf{u}_{2} \mathbf{C o}-\left(\mathbf{H}_{2} \mathbf{O}\right)_{4}$ complex, that is capable at this $\mathrm{pH}$ of catalytically oxidizing water to molecular dioxygen chemically, electrochemically and photochemically. Finally, while a few detailed $\mathrm{H}_{2}{ }^{18} \mathrm{O}$ labelling experiments have been described for $\mathrm{Ru}$ complexes ${ }^{\mathbf{1 3 , 3 9 - 5 1}}$ that allow the tracing of the $\mathrm{O}-\mathrm{O}$ bond formation step, this type of information is lacking for first row transition water oxidation catalysts. Our $\mathrm{H}_{2}{ }^{18} \mathrm{O}$ labelling experiments constitute the first example where the $\mathrm{O}-\mathrm{O}$ bond formation step has been elucidated based on labeling experiments.

\section{Acknowledgements}

We thank MINECO (CTQ-2013-49075-R, SEV-2013-0319, CTQ2014-52974-REDC, ENE2014-52280-REDT, CTQ201232247), the Feder funds and the EU COST actions CM1202 and CM1205. L. M. thanks "ICIQ-Foundation" for a Ph.D. grant. S. M. gratefully acknowledges "INSPIRE Faculty Award" by Government of India (No. DST/INSPIRE Faculty Award/2012/ $\mathrm{CH}-72$ ), and ISIRD research grant from IIT Kharagpur (project code: SMR). C. E. C.'s acknowledges the MICINN for 
a postdoctoral grant. The authors wish to thank (for financial support) the LABEX ARCANE (ANR-11-LABX-0003-01) for the project $\mathrm{H}_{2}$ Photocat including the C. E. C.'s post-doctoral fellowship. This work was also supported by ICMG FR 2067 and COST CM1202 program (PERSPECT $\mathrm{H}_{2} \mathrm{O}$ ). The Reseau National de RPE interdisciplinaire TGE CNRS is also thanked for EPR measurements and facilities.

\section{Notes and references}

1 S. Berardi, S. Drouet, L. Francas, C. Gimbert-Surinach, M. Guttentag, C. Richmond, T. Stoll and A. Llobet, Chem. Soc. Rev., 2014, 43, 7501-7519.

2 I. López, M. Z. Ertem, S. Maji, J. Benet-Buchholz, A. Keidel, U. Kuhlmann, P. Hildebrandt, C. J. Cramer, V. S. Batista and A. Llobet, Angew. Chem., Int. Ed., 2014, 53, 205-209.

3 M. L. Rigsby, S. Mandal, W. Nam, L. C. Spencer, A. Llobet and S. S. Stahl, Chem. Sci., 2012, 3, 3058-3062.

4 M. D. Kärkäs, O. Verho, E. V. Johnston and B. Åkermark, Chem. Rev., 2014, 114, 11863-12001.

5 J. T. Muckerman, M. Kowalczyk, Y. M. Badiei, D. E. Polyansky, J. J. Concepcion, R. Zong, R. P. Thummel and E. Fujita, Inorg. Chem., 2014, 53, 6904-6913.

6 M. Wiechen, M. M. Najafpour, S. I. Allakhverdiev and L. Spiccia, Energy Environ. Sci., 2014, 7, 2203-2212.

7 M. V. Sheridan, B. D. Sherman, Z. Fang, K.-R. Wee, M. K. Coggins and T. J. Meyer, ACS Catal., 2015, 5, 44044409.

8 L. Tong, R. Zong, R. Zhou, N. Kaveevivitchai, G. Zhang and R. P. Thummel, Faraday Discuss., 2015, 185, 87-104.

9 J. D. Blakemore, R. H. Crabtree and G. W. Brudvig, Chem. Rev., 2015, 115, 12974-13005.

10 R. L. House, N. Y. M. Iha, R. L. Coppo, L. Alibabaei, B. D. Sherman, P. Kang, M. K. Brennaman, P. G. Hoertz and T. J. Meyer, J. Photochem. Photobiol., C, 2015, 25, 32-45.

11 S. Karlsson, J. Boixel, Y. Pellegrin, E. Blart, H.-C. Becker, F. Odobel and L. Hammarstrom, Faraday Discuss., 2012, 155, 233-252.

12 L. Duan, F. Bozoglian, S. Mandal, B. Stewart, T. Privalov, A. Llobet and L. Sun, Nat. Chem., 2012, 4, 418-423.

13 S. Neudeck, S. Maji, I. López, S. Meyer, F. Meyer and A. Llobet, J. Am. Chem. Soc., 2013, 136, 24-27.

14 A. C. Sander, S. Maji, L. Francàs, T. Böhnisch, S. Dechert, A. Llobet and F. Meyer, ChemSusChem, 2015, 8, 1697-1702.

15 P. Garrido-Barros, I. Funes-Ardoiz, S. Drouet, J. BenetBuchholz, F. Maseras and A. Llobet, J. Am. Chem. Soc., 2015, 137, 6758-6761.

16 E. A. Karlsson, B.-L. Lee, T. Åkermark, E. V. Johnston, M. D. Kärkäs, J. Sun, Ö. Hansson, J.-E. Bäckvall and B. Åkermark, Angew. Chem., Int. Ed., 2011, 50, 11715-11718.

17 H. Yoon, Y.-M. Lee, X. Wu, K.-B. Cho, R. Sarangi, W. Nam and S. Fukuzumi, J. Am. Chem. Soc., 2013, 135, 9186-9194.

18 E. Y. Tsui, R. Tran, J. Yano and T. Agapie, Nat. Chem., 2013, 5, 293-299.

19 K. N. Ferreira, T. M. Iverson, K. Maghlaoui, J. Barber and S. Iwata, Science, 2004, 303, 1831-1838.
20 H. Dau, C. Limberg, T. Reier, M. Risch, S. Roggan and P. Strasser, ChemCatChem, 2010, 2, 724-761.

21 C. Sens, I. Romero, M. Rodríguez, A. Llobet, T. Parella and J. Benet-Buchholz, J. Am. Chem. Soc., 2004, 126, 7798-7799.

22 L. Mognon, J. Benet-Buchholz, S. M. W. Rahaman, C. Bo and A. Llobet, Inorg. Chem., 2014, 53, 12407-12415.

23 S. Roeser, M. Z. Ertem, C. Cady, R. Lomoth, J. BenetBuchholz, L. Hammarström, B. Sarkar, W. Kaim, C. J. Cramer and A. Llobet, Inorg. Chem., 2011, 51, 320-327. 24 S. Romain, J. Rich, C. Sens, T. Stoll, J. Benet-Buchholz, A. Llobet, M. Rodriguez, I. Romero, R. Clérac, C. Mathonière, C. Duboc, A. Deronzier and M. N. 1. Collomb, Inorg. Chem., 2011, 50, 8427-8436.

25 P. Pietrzyk, M. Srebro, M. Radoń, Z. Sojka and A. Michalak, J. Phys. Chem. A, 2011, 115, 2316-2324.

26 S. Varma, C. E. Castillo, T. Stoll, J. Fortage, A. G. Blackman, F. Molton, A. Deronzier and M.-N. Collomb, Phys. Chem. Chem. Phys., 2013, 15, 17544-17552.

27 S. Romain, J.-C. Leprêtre, J. Chauvin, A. Deronzier and M.-N. Collomb, Inorg. Chem., 2007, 46, 2735-2743.

28 M. Fabre and J. Bonvoisin, J. Am. Chem. Soc., 2007, 129, 1434-1444.

29 F. Lloret, M. Julve, J. Cano, R. Ruiz-García and E. Pardo, Inorg. Chim. Acta, 2008, 361, 3432-3445.

30 J. Limburg, J. S. Vrettos, H. Chen, J. C. de Paula, R. H. Crabtree and G. W. Brudvig, J. Am. Chem. Soc., 2001, 123, 423-430.

31 J. Gilbert, L. Roecker and T. J. Meyer, Inorg. Chem., 1987, 26, 1126-1132.

32 D. T. Sawyer, A. Sobkowiak and T. Matsushita, Acc. Chem. Res., 1996, 29, 409-416.

33 W. N. Oloo, A. J. Fielding and L. Que, J. Am. Chem. Soc., 2013, 135, 6438-6441.

34 J. P. Hage, A. Llobet and D. T. Sawyer, Bioorg. Med. Chem., 1995, 3, 1383-1388.

35 J. Bernadou, A.-S. Fabiano, A. Robert and B. Meunier, J. Am. Chem. Soc., 1994, 116, 9375-9376.

36 L.-P. Wang and T. Van Voorhis, J. Phys. Chem. Lett., 2011, 2, 2200-2204.

37 X. Sala, M. Z. Ertem, L. Vigara, T. K. Todorova, W. Chen, R. C. Rocha, F. Aquilante, C. J. Cramer, L. Gagliardi and A. Llobet, Angew. Chem., Int. Ed., 2010, 49, 7745-7747.

38 X. Sala, S. Maji, R. Bofill, J. García-Antón, L. Escriche and A. Llobet, Acc. Chem. Res., 2014, 47, 504-516.

39 D. Geselowitz and T. J. Meyer, Inorg. Chem., 1990, 29, 38943896.

40 C. W. Chronister, R. A. Binstead, J. Ni and T. J. Meyer, Inorg. Chem., 1997, 36, 3814-3815.

41 R. A. Binstead, C. W. Chronister, J. Ni, C. M. Hartshorn and T. J. Meyer, J. Am. Chem. Soc., 2000, 122, 8464-8473.

42 J. K. Hurst, J. Zhou and Y. Lei, Inorg. Chem., 1992, 31, 10101017.

43 Y. Lei and J. K. Hurst, Inorg. Chem., 1994, 33, 4460-4467.

44 Y. Lei and J. K. Hurst, Inorg. Chim. Acta, 1994, 226, 179-185.

45 H. Yamada and J. K. Hurst, J. Am. Chem. Soc., 2000, 122, 5303-5311. 
46 H. Yamada, T. Koike and J. K. Hurst, J. Am. Chem. Soc., 2001, 123, 12775-12780.

47 H. Yamada, W. F. Siems, T. Koike and J. K. Hurst, J. Am. Chem. Soc., 2004, 126, 9786-9795.

48 S. Romain, F. Bozoglian, X. Sala and A. Llobet, J. Am. Chem. Soc., 2009, 131, 2768-2769.

49 F. Bozoglian, S. Romain, M. Z. Ertem, T. K. Todorova, C. Sens, J. Mola, M. Rodríguez, I. Romero, J. Benet-
Buchholz, X. Fontrodona, C. J. Cramer, L. Gagliardi and A. Llobet, J. Am. Chem. Soc., 2009, 131, 15176-15187.

50 L. Vigara, M. Z. Ertem, N. Planas, F. Bozoglian, N. Leidel, H. Dau, M. Haumann, L. Gagliardi, C. J. Cramer and A. Llobet, Chem. Sci., 2012, 3, 2576-2586.

51 A. M. Angeles-Boza, M. Z. Ertem, R. Sarma, C. H. Ibanez, S. Maji, A. Llobet, C. J. Cramer and J. P. Roth, Chem. Sci., 2014, 5, 1141-1152. 